\title{
Regional Variability in preproEndothelin-1 Gene Expression in Sheep Pulmonary Artery and Lung during the Onset of Air-induced Chronic Pulmonary Hypertension Participation of Arterial Smooth Muscle Cells
}

\author{
Elena Tchekneva, ${ }^{\star}$ Thomas Quertermous, ${ }^{*}$ Brian W. Christman, ${ }^{\star}$ Mayme L. Lawrence, ${ }^{\ddagger}$ and Barbara Meyrick \\ $*$ Department of Medicine and ${ }^{\ddagger}$ Department of Pathology, Vanderbilt University Medical Center, Nashville, Tennessee $37232-2650$
}

\begin{abstract}
We investigated preproendothelin-1 (ppET-1) gene expression in the main and midregion pulmonary artery, and peripheral lung from control sheep and from animals during the development of the structural and functional changes of air-induced chronic pulmonary hypertension (CPH). Measurement of ET-1 in lung lymph $(n=7)$ at $1,4,8$, and $12 \mathrm{~d}$ of continuous air embolization (CAE) showed a significant increase from day 4 compared with controls $(n=4)$. A semiquantitative reverse transcription PCR for ppET-1 gene expression was developed using ovine-specific primers. Control sheep showed strikingly fewer ppET-1 transcripts in the midregion (22.9 $\pm 2.3 \mathrm{ng}$ cDNA equivalents) than in the main pulmonary artery and lung (736.0 \pm 263.7 and $705.5 \pm 125.7$, respectively). Smooth muscle cells (SMC) isolated from the main and midregion artery of control sheep confirmed these findings and showed higher levels of intracellular ET-1 synthesis in the main versus the midregion artery. Differences in gene expression persisted during CAE. In main pulmonary artery and lung, ppET-1 transcripts fell to $<1 \%$ of controls. However, transcripts in the midregion artery showed a gradual increase. Coincubation of SMC from the midregion with ET-1 plus TGF- $\beta$ resulted in an increase in intracellular big ET-1 and a decrease in SMC from the main artery. We conclude that SMC from the main and midregion pulmonary artery are phenotypically different and suggest that local synthesis of ET-1 and TGF- $\beta$, and increased levels of ET-1 in lung lymph, regulate ppET-1 gene expression and synthesis in arterial SMC during the development of air-induced CPH. (J. Clin. Invest. 1998. 101:1389-1397.) Key words: structural remodeling • lung lymph • semiquantitative reverse transcription PCR • big endothelin-1
\end{abstract}

\section{Introduction}

Chronic pulmonary diseases such as emphysema, obstructive lung disease, lung fibrosis, and the adult respiratory distress

Address correspondence to Dr. Elena Tchekneva, Center for Lung Research, T-1217 Medical Center North, Vanderbilt University Medical Center, Nashville, TN 37232-2650. Phone: 615-322-3412; FAX: 615-343-7448; E-mail: barbara.meyrick@mcmail.vanderbilt.edu

Received for publication 13 May 1997 and accepted in revised form 30 December 1997.

J. Clin. Invest.

(C) The American Society for Clinical Investigation, Inc. 0021-9738/98/03/1389/09 \$2.00

Volume 101, Number 6, March 1998, 1389-1397

http://www.jci.org syndrome are often accompanied by the development of chronic pulmonary hypertension $(\mathrm{CPH}) .^{1}$ The pathogenesis of $\mathrm{CPH}$ remains poorly understood. Earlier studies in our model of $\mathrm{CPH}$, continuous air embolization (CAE) into sheep pulmonary artery, suggest that the onset of the hypertension and accompanying structural changes involves early endothelial injury $(1,2)$. Such injury may be associated with alterations in endothelin-1 (ET-1) gene expression.

Proteins of the endothelin family are produced in a variety of tissues, such as kidney, intestine, brain, and adrenal gland and may vary in the type of endothelin (ET-1, -2, and -3) produced (3). ET-1 is the major form produced in the lung, where it is known to modulate vascular tone and to induce a slowly developing and sustained pulmonary vasoconstriction $(3,4)$. Mature ET-1 results from conversion of big ET-1 by endothelin-converting enzyme (ECE) (5), and its final removal from the circulation involves a neutral endopeptidase that metabolizes the active form (6). ET-1 is also known to be a smooth muscle mitogen (7). Recent papers have indicated that alterations in ET-1 gene expression in lungs of patients with primary and chronic pulmonary hypertension (8) and animal models of CPH may contribute to its onset (9-11), although the findings are not consistent. For example, ET-1 gene expression is known to be increased in the lungs of a rat model of idiopathic pulmonary hypertension (9). Chronic exposure to hypoxia is known to result in increased plasma concentrations of ET-1 and upregulation of ET-1 mRNA in rat lung (10), whereas monocrotaline-induced $\mathrm{CPH}$ is associated with an increase in plasma levels of ET-1 but a decrease in ET-1 mRNA in rat lung (11). Whether ET-1 gene expression is similar throughout the normal and remodeled pulmonary arterial circulation has not been examined.

To determine whether ET-1 contributes to the development of $\mathrm{CPH}$ in sheep receiving CAE, we measured ET-1 in lung lymph after $0,1,4,8$, and $12 \mathrm{~d}$ of CAE and determined the effect of CAE on prepro (pp)ET-1 gene expression in two levels of the pulmonary vasculature, main and midregion pulmonary artery, and the lung, using a semiquantitative reverse transcription (RT) PCR technique. We also examined basal and ET-1-stimulated and ET-1 plus TGF- $\beta$-stimulated ET-1 synthesis in smooth muscle cells (SMC) isolated from the main and midregion pulmonary artery. Our results are the first to demonstrate that the ET- 1 gene is differentially expressed in control pulmonary artery and lung: that the onset of the structural and functional changes of CAE-induced $\mathrm{CPH}$ is accom-

1. Abbreviations used in this paper: CAE, continuous air embolization; $\mathrm{CO}$, cardiac output; $\mathrm{CPH}$, chronic pulmonary hypertension; ECE, endothelin-converting enzyme; ET-1, endothelin-1; $P_{\mathrm{la}}$, left atrial pressure; pp, prepro; $P_{\mathrm{pa}}$, pulmonary artery pressure; $P_{\mathrm{sa}}$, systemic artery pressure; PVR, pulmonary vascular resistance; RT, reverse transcription; SMC, smooth muscle cell(s). 
panied by a sustained increase in ET-1 flux from the lung and in differential effects on ppET-1 gene expression in the main and midregion pulmonary artery, and in lung.

\section{Methods}

Sheep model of $\mathrm{CPH}$. We have described previously our protocol for inducing $\mathrm{CPH}$ by CAE delivered into the pulmonary artery of chronically catheterized sheep with a lung lymph fistula $(1,2,12)$. Briefly, bilateral thoracotomies were performed on yearling sheep under general anesthesia, pulmonary artery and left atrial catheters were inserted, and a catheter was placed in the efferent duct of the caudal mediastinal lymph node. Jugular venous and carotid artery catheters were also placed through a neck incision. The sheep were allowed to recuperate for a week, a thermodilution catheter was positioned in the pulmonary circulation through a jugular vein introducer, and baseline physiological measurements were assessed. The sheep then received CAE into the pulmonary artery by way of the proximal port (lying in the right heart) of the thermodilution catheter for either 1, 4, 8 , or $12 \mathrm{~d}$. Surgically prepared animals not receiving air but maintained for the same time periods served as controls. Physiological and structural data for this model of $\mathrm{CPH}$ have been reported previously $(1,2,12)$. Tissue samples were collected from control (day 0$)$ sheep and animals receiving CAE for either $1,4,8$, or $12 \mathrm{~d}(n=2$ for each time point).

Protocol. Measurements of mean pulmonary artery pressure $\left(P_{\mathrm{pa}}\right)$, left atrial pressure $\left(P_{\mathrm{la}}\right)$, systemic artery pressure $\left(P_{\mathrm{sa}}\right)$, and cardiac output (CO) were made on a daily basis. Pulmonary vascular resistance (PVR) was calculated using the formula $P_{\mathrm{pa}}-P_{\mathrm{la}} / \mathrm{CO}$. Air flow into the pulmonary circulation was maintained at a rate that resulted in a PVR that was 2.5 times baseline $(1,2,12)$. On days 4,8 , and 12, CAE was stopped for a period of $1-2 \mathrm{~h}$ to allow the animals to equilibrate, and hemodynamic monitoring was repeated (off air). On days $0,1,4,8$, and 12 of CAE, lung lymph flow over a 15-min period was monitored, and EDTA-anticoagulated lung lymph and plasma samples taken from the jugular vein were collected for measurement of protein concentration by a modified Biuret method using an autoanalyzer and for measurement of ET-1 levels (see below).

Tissue collection. After $0,1,4,8$, and $12 \mathrm{~d}$ of CAE, the animals were killed by an overdose of barbiturates. The lungs were removed intact from the chest, and tissue samples were collected from the main pulmonary artery, the midregion axial intrapulmonary artery (between the eighth and ninth generation of the axial pathway), and lung, an indicator of ET-1 levels in the peripheral vasculature. The latter two samples came from the right lower lobe. The main and midregion pulmonary artery samples were dissected from adjacent tissues and adventitia. All samples were frozen immediately for later isolation of total RNA. An adjacent block of tissue was taken from each sheep from the main and midregion pulmonary artery and peripheral lung and fixed overnight at $4{ }^{\circ} \mathrm{C}$ in $4 \%$ paraformaldehyde in PBS, pH 7.4, for routine light microscopy to check for structural remodeling and for in situ hybridization.

In situ hybridization. In situ hybridization of ppET-1 mRNA was carried out using a $\left[{ }^{35} \mathrm{~S}\right] \mathrm{dUTP}$-labeled probe consisting of a 200-base fragment of the sheep ppET-1 cDNA (13). Standard methodology for detection of the ppET- 1 mRNA was carried out using $4-\mu \mathrm{m}$ sections from each level of artery and from peripheral lung $(14,15)$.

Cell culture. SMC were isolated from the main and midregion pulmonary artery of control sheep using a modified explant technique (16). After removing the endothelial, luminal, and adventitial layers by gentle scraping with a scalpel blade, the remaining explants were placed inner medial side down onto $100-\mathrm{mm}$ culture dishes in RPMI 1640 containing $100 \mathrm{U} / \mathrm{ml}$ penicillin, $100 \mu \mathrm{g} / \mathrm{ml}$ streptomycin, $40 \mu \mathrm{g} / \mathrm{ml}$ gentamicin, $2 \mathrm{mM}$ L-glutamine (GIBCO BRL, Gaithersburg, MD) and $15 \%$ heat-inactivated calf serum (Atlanta Biologicals, Norcross, GA). Explants were removed after $2 \mathrm{~d}$, and cells were passed once a week by harvesting with $0.05 \%$ Trypsin in $0.53 \mathrm{mM}$
EDTA. The smooth muscle origin of the cells was assessed by their "hill and valley" morphology, absence of Factor VIII/von Willebrand antigen, and presence of smooth muscle $\alpha$-actin. The cells were maintained and used in the log phase and between passages 3 and 4 for each experiment. Experiments were carried out in unstimulated cells after $18 \mathrm{~h}$ incubation with $0.1 \%$ calf serum in RPMI; additional preliminary studies were carried out in cells after incubation with either $10 \mathrm{nM}$ ET-1 or after coincubation with $10 \mathrm{nM}$ ET-1 plus $100 \mathrm{ng} / \mathrm{ml}$ TGF- $\beta$ in $0.1 \%$ calf serum in RPMI for $18 \mathrm{~h}$. End-points include assessment of ppET-1 mRNA and measurement of intracellular ET-1 and big ET-1 in unstimulated and in stimulated cells. Each experiment was carried out in duplicate from three different arterial samples $(n=3)$.

Endothelial cells were used as controls for ppET-1 gene expression. Endothelial cells were cultured from sheep main pulmonary artery and lung microvasculature as described previously $(17,18)$. Confluent endothelial monolayers between passages 6 and 8 were used for these experiments.

Extraction of ET-1 and big ET-1 from SMC. At the end of the experiment, cells were washed twice in PBS and trypsinized, and cell number was counted using a hemocytometer. After centrifugation at $1,000 \mathrm{rpm}$ for $10 \mathrm{~min}$, the cell pellets were homogenized in $400 \mu \mathrm{l}$ of $0.1 \%$ Triton X-100 using a Teflon-glass pestle, and the cell homogenates were centrifuged at 3,000 rpm for $15 \mathrm{~min}$. The supernatants were acidified with $2 \mathrm{M} \mathrm{HCl}(1: 4)$ and then dried and reconstituted in assay buffer for measurements of intracellular mature and big ET-1. ET-1 was measured by an ELISA (Biotrack system; Amersham International, Little Chalfont, UK). The assay is sensitive to values of $>1 \mathrm{fmol}$ and cross-reacts $100 \%$ with ET-1 and ET-2 (ET-2 is not generally found in the lung or pulmonary smooth muscle) but not with ET-3. Similarly, big ET-1 was measured by an ELISA (Biotrack system). Cross-reactivity of the big ET-1 antibody is $100 \%$ for big ET-1 and $<0.003 \%$ for big ET-2 and big ET-3. Each sample was run in duplicate from three separate experiments $(n=3)$.

Measurements of ET-1 in lung lymph. ET-1 levels were measured in $1 \mathrm{ml}$ aliquots of cell free lung lymph and serum using an RIA (NEN Research Products, Boston, MA). This assay cross-reacts with $100 \%$ of ET- 1 and shows $50 \%$ cross-reactivity with ET-2 and big ET-1. Samples were extracted using preconditioned C18 columns and eluted with $0.05 \mathrm{~mol} / \mathrm{liter}$ ammonium bicarbonate in methanol. The samples were then dried and reconstituted in assay buffer, and the RIA was run according to specifications from the manufacturer. Each sample was run in duplicate. The assay is sensitive to values $>9.5 \mathrm{pg} / \mathrm{ml}$.

Semiquantitative analysis of ppET-1 transcripts by RT-PCR. Total RNA was isolated from lung tissue, vascular wall segments, and cultured smooth muscle and endothelial cells after homogenization in RNA STAT- $60^{\circledR}$ reagent (Tel-Test, Inc., Friendswood, TX) according to the manufacturer's protocol. Using the cDNA sequence for sheep ppET-1 (13), sense and antisense primers were synthesized (model 373A; Applied Biosystems, Inc., Foster City, CA): 5' TTG TGG CTT TCC AAG GAG CTC CAG 3' (bases 298-321) and 5' CGG TTG TCC CAG GCT TTC ATG 3' (bases 694-678). These primers were from regions of consensus between the sheep, human, cow, and pig ET-1 gene.

We developed an RT-PCR technique to allow semiquantitative analysis of ppET-1 gene expression. To maximize specificity, we examined different annealing temperatures $\left(50,60,65\right.$, and $\left.67^{\circ} \mathrm{C}\right)$ and numbers of cycles $(25,30,33$, and 35). Optimal expression of the ppET-1 gene was accomplished using 33 cycles and an annealing temperature of $60^{\circ} \mathrm{C}$. The conditions gave a single band on agarose gel electrophoresis of expected size (396 bases).

First-strand cDNA was obtained using RT of the ppET-1 mRNA, followed by PCR amplification. $4 \mu \mathrm{g}$ of total RNA was reverse-transcribed in a total volume containing $50 \mathrm{U} / \mu \mathrm{l}$ of human placenta RNase inhibitor, $1 \mathrm{mmol} /$ liter each of $\mathrm{dNTP}, 0.04 \mathrm{~A}_{260} \mathrm{U}$ of oligo$\mathrm{p}(\mathrm{dT})_{15}$ primer, $40 \mathrm{U}$ avian myeloblastosis virus reverse transcriptase in buffer, $50 \mathrm{mmol} /$ liter Tris-HCl, $8 \mathrm{mmol} /$ liter $\mathrm{MgCl}_{2}, 30 \mathrm{mmol} /$ liter $\mathrm{KCl}$, and $1 \mathrm{mmol} /$ liter DTT, $\mathrm{pH} 8.5$, at $20^{\circ} \mathrm{C}$. The $\mathrm{RT}$ reaction was carried out at $42^{\circ} \mathrm{C}$ for $1 \mathrm{~h}$. The reaction was stopped by heating the 
sample to $99^{\circ} \mathrm{C}$ for $5 \mathrm{~min}$. Removal of RNA was carried out in each sample by incubation with $1 \mathrm{U}$ RNase $\mathrm{H}$ at $37^{\circ} \mathrm{C}$ for $20 \mathrm{~min}$ followed by heating at $99^{\circ} \mathrm{C}$ for $5 \mathrm{~min}$. The samples were placed on ice after each heating cycle to allow condensation of evaporated water followed by a brief centrifugation. The ppET-1 first-strand cDNA was amplified by PCR. The sample mixture for PCR contained $1 \mu \mathrm{l}$ of RT sample, $42 \mu \mathrm{l}$ of distilled water, $0.5 \mu \mathrm{l} 5^{\prime}$ and $3^{\prime}$ primers $(20 \mathrm{mmol} /$ liter each), $5 \mu \mathrm{l} 10 \times \mathrm{PCR}$ buffer $(10 \mathrm{mmol} / \mathrm{liter}$ Tris- $\mathrm{HCl}, 15 \mathrm{mmol} / \mathrm{liter}$ $\mathrm{MgCl}_{2}, 500 \mathrm{mmol} / \mathrm{liter} \mathrm{KCl}[\mathrm{pH} 8.3]$, and $1.25 \mathrm{U}$ Taq DNA polymerase). All of the chemicals used for RT-PCR were from Boehringer Mannheim Biochemicals (Indianapolis, IN). Each reaction mixture was overlaid with $37 \mu$ l of mineral oil (Sigma Chemical Co., St. Louis, MO). The thermocycler (BIOS Corp., New Haven, CT) was programmed for 33 cycles at $94^{\circ} \mathrm{C}$ for $1 \mathrm{~min}, 60^{\circ} \mathrm{C}$ for $1 \mathrm{~min}$, and $72^{\circ} \mathrm{C}$ for $2 \mathrm{~min}$. The resultant mixture was separated electrophoretically on a $1.8 \%$ agarose gel, and the cDNA bands were visualized after ethidium bromide staining. Negative controls included samples without addition of mRNA before RT reaction, and samples without addition of avian myoblastosis virus reverse transcriptase, to confirm the absence of any contaminating genomic DNA. OD of the cDNA bands was determined by a computerized inverted image analysis system (Image Store 7500; UVP Inc., Upland, CA) and densitometry (UltraScan 2202; LKB, Uppsala, Sweden). Data from each sample were normalized to serial dilutions obtained from day 0 (control) animals. Actin and tubulin proved unsuccessful as loading markers, since each showed an increase in signal in samples after CAE. Samples from each level of the pulmonary artery and lung from two animals were examined at each period of CAE.

Construction of standard regression lines. Regression lines for calibration were constructed for both levels of pulmonary artery and lung to allow quantification of signal strength in each sample after CAE. The RT reaction product (derived from $4 \mu \mathrm{g}$ of total RNA) containing the first-strand ppET-1 cDNA was diluted 1:8 for lung and 1:5 for main and midregion pulmonary artery. These dilutions gave a concentration of $500 \mathrm{ng}$ cDNA equivalents of mRNA for lung and $800 \mathrm{ng}$ for main and midregion pulmonary artery. For each of the standards, these values were taken as the highest concentration, and serial dilutions were made from each of these samples. Fivefold serial dilutions were made for the lung, and threefold dilutions were made

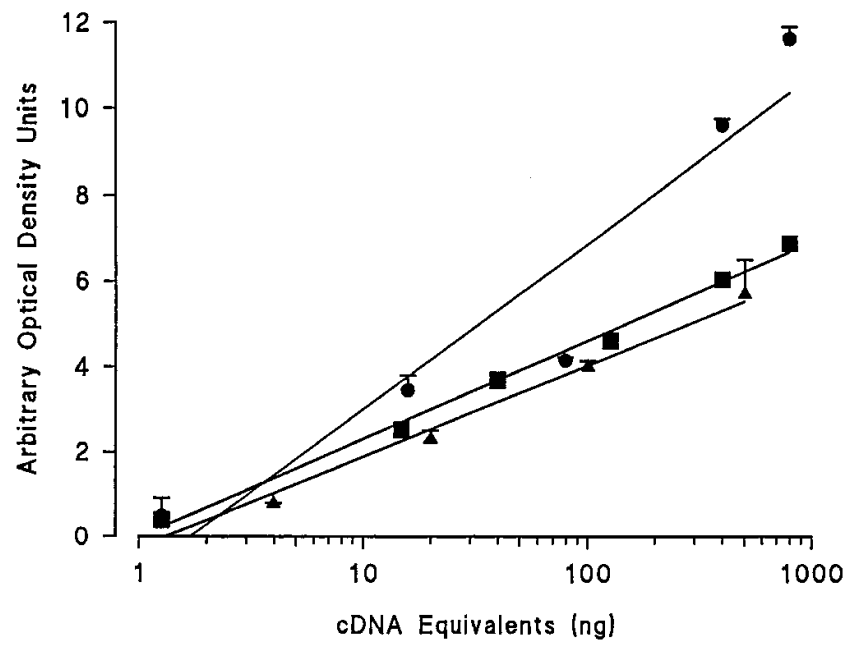

Figure 1. Representative linear regressions for serial dilutions of RT products as cDNA equivalents of mRNA in nanograms. Regression lines were generated using serial dilutions (threefold for main [ $\mathbf{\square}]$

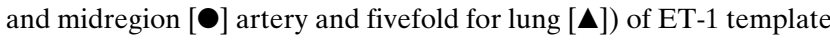
cDNA from control sheep, and coamplified by PCR. The reaction was carried out using 33 cycles and an annealing temperature of $60^{\circ} \mathrm{C}$. Two independent OD measurements were made for each time point. for the main and midregion pulmonary artery. Each of the serial dilutions of the reverse-transcribed mRNA underwent PCR as described above. Linear regressions for each sample with corresponding cDNA equivalents of mRNA in nanograms are shown in Fig. 1. The values for each experimental point from arteries and lung were taken from readings on the appropriate regression line and are given as firststrand cDNA equivalents in nanograms.

Statistics. Results for physiological variables as well as plasma and lung lymph samples are presented as mean \pm SEM. Values for CAE-treated animals were compared to day 0 using an ANOVA followed by Tukey's multiple comparison test. Values for comparison of CAE-treated animals with time-matched controls were compared using the Student's $t$ test. Values of $P<0.5$ were considered significant. One-way ANOVA for variables in control animals revealed no statistical differences.

\section{Results}

Effect of CAE on pulmonary hemodynamics. As demonstrated in earlier studies, CAE into the pulmonary arterial circulation of sheep over a period of $12 \mathrm{~d}$ leads to the development of $\mathrm{CPH}(1,2,12)$. During the $12 \mathrm{~d}$ of CAE, PVR was maintained at a level that was $\sim 2.5$ times greater than baseline (ANOVA $<0.05$; Fig. 2). When air flow was stopped for a period of 1-2 h (off air), PVR fell in comparison to the on air value but was always significantly elevated above the timematched controls: after 8 and $12 \mathrm{~d}$ of CAE, PVR (off air) was maintained at a level similar to the animals receiving CAE. The PVR of untreated controls remained unchanged throughout the $12 \mathrm{~d}$ of the experiment (Fig. 2). Mean $P_{\mathrm{pa}}$ (off air) was elevated significantly at 8 and $12 \mathrm{~d}$ of CAE when it was similar to the on air values (Table I). $P_{\text {la }}$ was decreased significantly during CAE whether measured on or off air (ANOVA $<0.05$; Table I). CO and $P_{\mathrm{sa}}$ showed a small fall over the $12 \mathrm{~d}$ of the experiment and were similar whether the sheep were on or off air (Table I). Some of these data have been reported previously (19).

Effect of CAE on flux of ET-1 from the lung. A rapid and sustained increase in lung lymph flow $($ ANOVA $<0.05)$ in the absence of any alteration in the ratio of lymph to plasma protein concentration was found when compared with timematched controls and day 0 (ANOVA $<0.05$; Table II). Abso-

Table I. Mean $P_{p a}, P_{l a}, C O$, and Mean $P_{\text {sa }}$ during CAE (On Air) and "Off Air" at 0, 1, 4, 8, and $12 d$

\begin{tabular}{lccccc}
\hline $\begin{array}{l}\text { Days of CAE } \\
P_{\mathrm{pa}}\left(\mathrm{cm} \mathrm{H} \mathrm{H}_{2} \mathrm{O}\right)\end{array}$ & 0 & 1 & 4 & 8 & 12 \\
$\quad$ On air & $19 \pm 1$ & $32 \pm 3^{*}$ & $\begin{array}{l}27 \pm 3^{*} \\
20 \pm 2^{\ddagger}\end{array}$ & $\begin{array}{l}25 \pm 3 \\
26 \pm 3^{*}\end{array}$ & $\begin{array}{c}30 \pm 2^{*} \\
27 \pm 2^{*}\end{array}$ \\
$\quad$ Off air & $19 \pm 1$ & & & & \\
$\left.P_{\mathrm{la}(\mathrm{cm} \mathrm{H}} \mathrm{O}\right)$ & & & & & \\
$\quad$ On air & $-1 \pm 1$ & $-6 \pm 1^{*}$ & $-6 \pm 1^{*}$ & $-6 \pm 1^{*}$ & $-4 \pm 1$ \\
Off air & $-1 \pm 1$ & & $-6 \pm 1^{*}$ & $-5 \pm 1^{*}$ & $-4 \pm 1$ \\
CO (liter/min $)$ & & & & & \\
On air & $4.8 \pm 0.3$ & $3.5 \pm 0.3$ & $3.3 \pm 0.3^{*}$ & $3.7 \pm 0.5$ & $3.6 \pm 0.5$ \\
Off air & $4.8 \pm 0.3$ & & $3.3 \pm 0.3$ & $3.6 \pm 0.5$ & $3.7 \pm 0.7$ \\
$P_{\text {sa }}($ Torr $)$ & & & & & \\
On air & $83 \pm 4$ & $79 \pm 2$ & $76 \pm 2$ & $78 \pm 3$ & $75 \pm 2$ \\
Off air & $83 \pm 4$ & & $76 \pm 3$ & $78 \pm 3$ & $73 \pm 2$ \\
& & & & & \\
\hline
\end{tabular}

Values are mean \pm SEM. $n=7 . * P<0.05$ compared with day 0 ; ${ }^{*} P<$ 0.05 compared with values on air. 


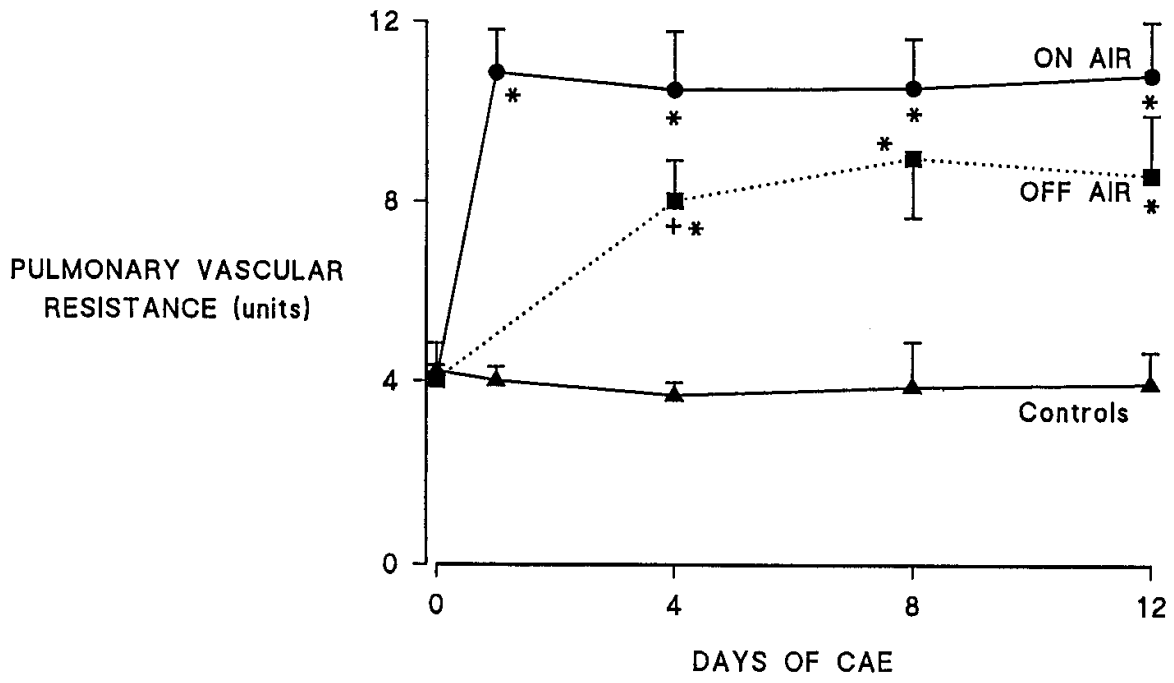

Figure 2. PVR in sheep during $12 \mathrm{~d}$ of CAE (on air, - ); after a 2-h period of equilibration (off air, $\mathbf{\square})(n=7)$; and in controls that were surgically prepared but did not receive air $(\boldsymbol{\Lambda}, n=7)$. Data are presented as mean \pm SEM. One-way ANOVA $<$ $0.05 ; * P<0.05$ compared with controls; ${ }^{+} P<0.05$ compared with on air value. lute values of lung lymph ET-1 were increased significantly, two to three times above time-matched controls and day 0 at 4 and $12 \mathrm{~d}$ of CAE (ANOVA $<0.05$; Table II). When calculated as flux of endothelin from the lung (absolute value of ET- $1 \times$ lung lymph flow over $15 \mathrm{~min}$ ), values were elevated significantly above time-matched controls by day 1 of CAE and peaked by day 8 (Fig. 3), and were elevated significantly above day 0 from day 4 (ANOVA $<0.05$ ). Plasma levels of ET-1 were similar to controls throughout the $12 \mathrm{~d}$ of CAE, with values between 0.9 and $2.4 \mathrm{pg} / \mathrm{ml}$ (Table II).

In situ hybridization of ppET-1 $m R N A$. To examine whether the increased ET-1 in lung lymph was due to increased expression of the ppET-1 gene, tissue sections from lung and main and midregion pulmonary artery were examined. We found minimal hybridization of the ppET-1 mRNA in control tissues taken from each level. Hybridization at each level in animals receiving CAE for $1,4,8$, and $12 \mathrm{~d}$ was not increased in the lung and main pulmonary artery compared with controls: a

Table II. Lung Lymph Flow $\left(Q_{L}\right)$, Lymph to Plasma Protein Concentration (L:P), and Lung Lymph and Plasma ET-1 Levels after 0, 1, 4, 8, and 12 d of Air Embolization

\begin{tabular}{lccccc}
\hline $\begin{array}{l}\text { Days of CAE } \\
\text { Q }(\mathrm{ml} / 15 \mathrm{~min})\end{array}$ & 0 & 1 & 4 & 8 & 12 \\
$\quad$ Air (7) & $1.1 \pm 0.1$ & $6.9 \pm 1.4^{*}$ & $4.4 \pm 0.4^{*}$ & $4.2 \pm 0.9^{*}$ & $3.3 \pm 0.4$ \\
Control (4) & $1.2 \pm 0.2$ & $1.1 \pm 0.3^{\ddagger}$ & $1.3 \pm 0.2^{\ddagger}$ & $1.6 \pm 0.6$ & $1.3 \pm 0.1$ \\
L:P & \multicolumn{5}{c}{} \\
$\quad$ Air (7) & $0.65 \pm 0.02$ & $0.66 \pm 0.06$ & $0.58 \pm 0.03$ & $0.58 \pm 0.04$ & $0.56 \pm 0.03$ \\
Control (4) & $0.64 \pm 0.01$ & $0.60 \pm 0.02$ & $0.57 \pm 0.02$ & $0.57 \pm 0.07$ & $0.54 \pm 0.03$ \\
Lung lymph ET-1 (pg/100 & $\mu \mathrm{l})$ \\
Air (7) & $1.2 \pm 0.4$ & $1.7 \pm 0.4$ & $3.2 \pm 0.6^{*}$ & $3.1 \pm 0.7$ & $4.4 \pm 1.3^{*}$ \\
Control (4) & $1.7 \pm 0.2$ & $1.7 \pm 0.4$ & $1.1 \pm 0.2^{\ddagger}$ & $1.6 \pm 0.6$ & $1.4 \pm 0.4$ \\
Plasma ET-1 (pg/ml) & & & & \\
$\quad$ Air (3) & $0.9 \pm 0.1$ & $1.2 \pm 0.2$ & $2.1 \pm 1.0$ & $0.9 \pm 0.1$ & $2.4 \pm 0.6$ \\
Control (4) & $0.9 \pm 0.1$ & $0.9 \pm 0.1$ & $0.9 \pm 0.1$ & $0.9 \pm 0.2$ & $1.4 \pm 0.3$
\end{tabular}

Data are shown as mean \pm SEM. $* P<0.05$ compared with day $0 ;{ }^{*} P<0.05$ compared with time-matched controls. Number of animals is shown in parenthesis. small increase in signal was suggested over the remodeled intimal layer of the midregion artery (data not shown). To confirm these findings, we carried out semiquantitative RT-PCR on tissue from the same regions from control and hypertensive sheep.

ppET-1 gene expression in control sheep and during CAE. Linear regressions for standards diluted from control samples for main and midregion pulmonary artery and peripheral lung are shown in Fig. 1. Each regression showed a correlation coefficient of 0.95 or greater. Using these standard lines, we found relatively similar amounts of ppET-1 gene expression in control peripheral lung and main pulmonary artery, while that in the midregion pulmonary artery was strikingly less (Table III). Air embolization resulted in a marked fall in ppET-1 gene expression in the peripheral lung and main pulmonary artery

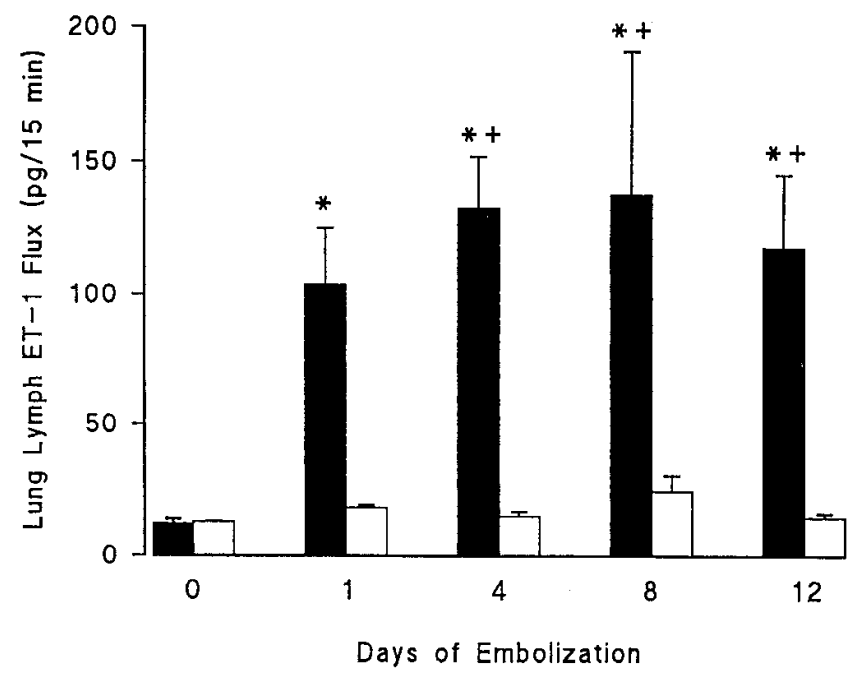

Figure 3. CAE causes an elevation in flux of ET-1 from the lung. Flux of ET-1 is the absolute value of ET-1 in lung lymph $\times$ lung lymph flow over a 15-min period. Black bars, Animals receiving CAE $(n=7)$; white bars, time-matched controls $(n=4)$. Data are shown as mean \pm SEM. ANOVA $<0.05 .{ }^{+} P<0.05$ compared with day 0 ; $* P<0.05$ compared with time-matched controls. 
Table III. Differential Expression of the ET-1 Gene in Peripheral Lung, and Midregion and Main Pulmonary Artery

\begin{tabular}{cccc}
\hline & \multicolumn{3}{c}{ ET-1 cDNA equivalents of mRNA (ng/mg tissue) } \\
\cline { 2 - 4 } CAE & Lung & Midregion PA & Main PA \\
\hline$d$ & & & \\
0 & $794.3: 616.6$ & $21.4: 24.5$ & $549.5: 922.5$ \\
1 & $11.8: 10.5$ & $24.5: 32.4$ & $50.1: 45.7$ \\
4 & $10.5: 3.9$ & $32.3: 37.2$ & $4.8: 4.8$ \\
8 & $9.4: 5.8$ & $40.7: 34.9$ & $5.6: 9.4$ \\
12 & $1.6: 2.0$ & $87.7: 104.8$ & $3.2: 3.5$ \\
\hline
\end{tabular}

Each value was obtained after densitometric measurement applied to the standard linear regressions shown in Fig. 1. Values of two independent measurements are presented. $P A$, Pulmonary artery.

(Fig. 4); this fall was less dramatic in the main pulmonary artery than in the lung. By day 1 of CAE, ppET-1 gene expression in the lung was reduced markedly below the day 0 value (mean for day $0=705.5 ; 1 \mathrm{~d}$ CAE $=11.2 \mathrm{ng}$ cDNA equivalents of mRNA) and continued to fall during the $12 \mathrm{~d}$ of CAE (mean $=1.8 \mathrm{ng}$ cDNA equivalents of mRNA; Table III). A similar dramatic fall in ppET-1 gene expression was found for
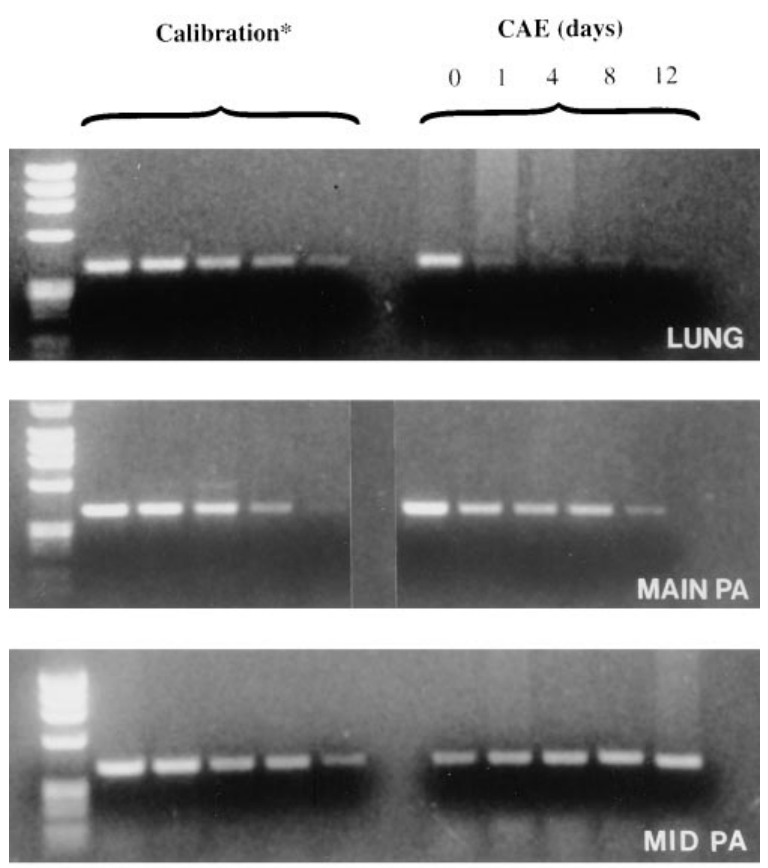

RNA equivalents of first strand cDNA (ng)

Figure 4. Representative data showing that the ppET-1 gene is differentially expressed in normal lung and in main and midregion pulmonary artery $(P A)$ and is altered during CAE. Left, PCR images of the ppET-1 cDNA after serial dilutions of the RT products from control lung and main and midregion pulmonary artery. Right, PCR images of ppET-1 cDNA from sheep receiving CAE for $0,1,4,8$, and $12 \mathrm{~d}$. The semiquantitative data obtained for each sample are shown in Table III. These values were obtained from the optimum temporal experiment for each region. The findings were reproducible in the two animals examined. the main pulmonary artery (mean for day $0=736.0 ; 1 \mathrm{~d}$ CAE $=$ 47.9; $12 \mathrm{~d}$ CAE $=3.3 \mathrm{ng}$ cDNA equivalents of mRNA; Table III). In contrast, ppET-1 gene expression in the midregion artery showed a gradual increase during CAE (Fig. 4) and by $12 \mathrm{~d}$ reached a value that was approximately four times that of day 0 (mean for day $0=22.9 ; 12 \mathrm{~d}$ CAE $=96.3 \mathrm{ng}$ cDNA equivalents of mRNA; Table III). These trends were reproducible in each of the other two animals examined at each tissue location.

ppET-1 gene expression in isolated SMC from control sheep. To confirm the differences in ppET-1 transcripts, we examined ppET-1 gene expression in SMC isolated from sheep main and midregion pulmonary artery and compared these findings with endothelial cells isolated from the sheep main pulmonary artery and peripheral lung as controls. Expression of the ppET-1 gene was evident in each cell type (Fig. 5). ppET-1 gene expression was greater in SMC isolated from the main than the midregion pulmonary artery, consistent with our RT-PCR findings for control artery at these two levels. As expected, endothelial cells showed ppET-1 gene expression, and similar to the findings for SMC, expression was higher in endothelial cells cultured from the main pulmonary artery than in those from the microvasculature.

Intracellular levels of big ET-1 and ET-1 in SMC. Compatible with our findings for ppET-1 gene expression in normal pulmonary artery and isolated SMC (Figs. 4 and 5), intracellular levels of big ET-1 and ET-1 in SMC isolated from the main pulmonary artery were greater than were found for those from the midregion (Fig. 6). Levels of intracellular big ET-1 in cells from the main pulmonary artery were seven times greater than in cells from the midregion, and mature ET-1 levels were 26 times greater in cells from the main than from the midregion pulmonary artery (Fig. 6).

Effect of exogenous ET-1 and ET-1 plus TGF- $\beta$ on big ET-1 and ET-1 in SMC. The response of SMC isolated from the main and midregion pulmonary artery to ET-1 alone and to ET-1 plus TGF- $\beta$ was different. After $18 \mathrm{~h}$ exposure to $10 \mathrm{mM}$ ET-1, cells from the main pulmonary artery showed a $40 \%$ reduction in big ET-1 and a $35 \%$ reduction after coincubation with TGF- $\beta$ plus ET-1 (Fig. $7 A$ ). Measurements of intracellular ET-1 revealed a striking 35-fold increase in response to exogenous ET-1, and a less marked, 15-fold increase in response

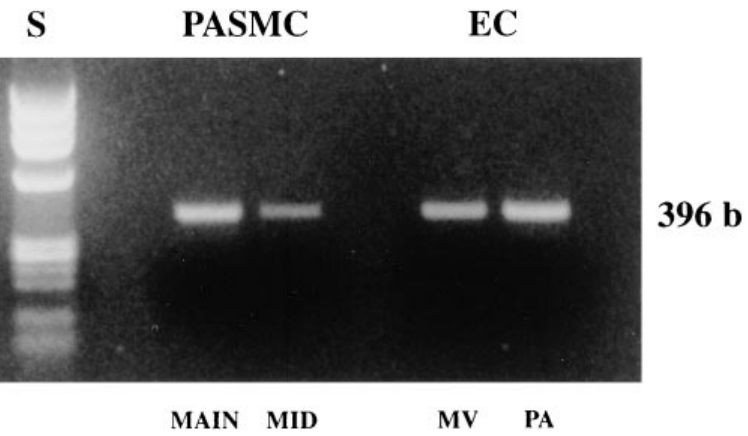

Figure 5. Representative RT-PCR data showing ppET-1 gene expression in SMC from the main and midregion pulmonary artery $(P A S M C)$, and endothelial cells $(E C)$ from the main pulmonary artery $(P A)$ and lung periphery $(M V)$ of sheep. SMC and endothelial cells from the main pulmonary artery express higher levels of ppET-1 transcripts than SMC from the midregion artery and microvascular endothelial cells. $S$, HaeIII DNA size marker. 


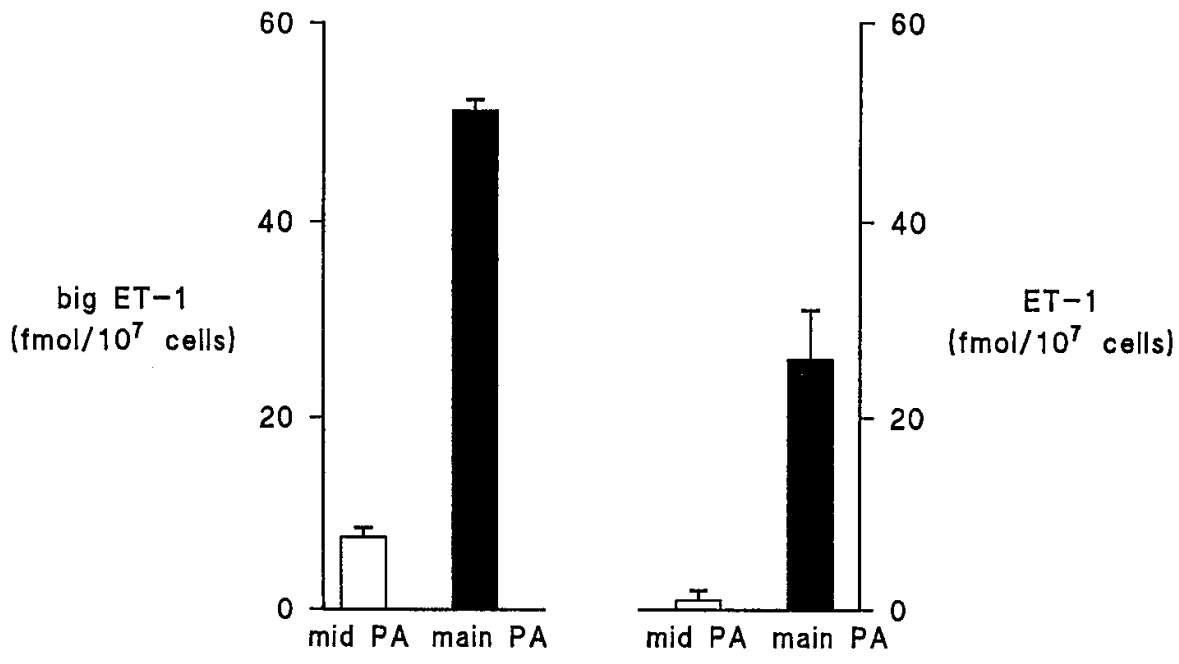

Figure 6. Concentrations of big ET-1 and mature ET-1 in SMC isolated from the main and midregion pulmonary artery $(P A)$ of control sheep. Data are presented as mean \pm SEM from replicates of three different cell lines. to ET-1 plus TGF- $\beta$ (Fig. 7 B). In contrast, cells from the midregion artery showed an $87 \%$ reduction in big ET-1 in response to ET-1, and a $100 \%$ increase after coincubation with ET-1 plus TGF- $\beta$. Intracellular levels of ET-1 in both cell types was increased markedly in response to exogenous ET-1 and remained at a similar level in response to ET-1 plus TGF- $\beta$ (Fig. 7 B).

\section{Discussion}

CAE into the sheep pulmonary artery results in the onset of sustained pulmonary hypertension and remodeling of the pulmonary arterial circulation, including medial and adventitial thickening in the main and large muscular arteries, medial and intimal thickening in the smaller $(<1,000 \mu \mathrm{m}$ external diame-
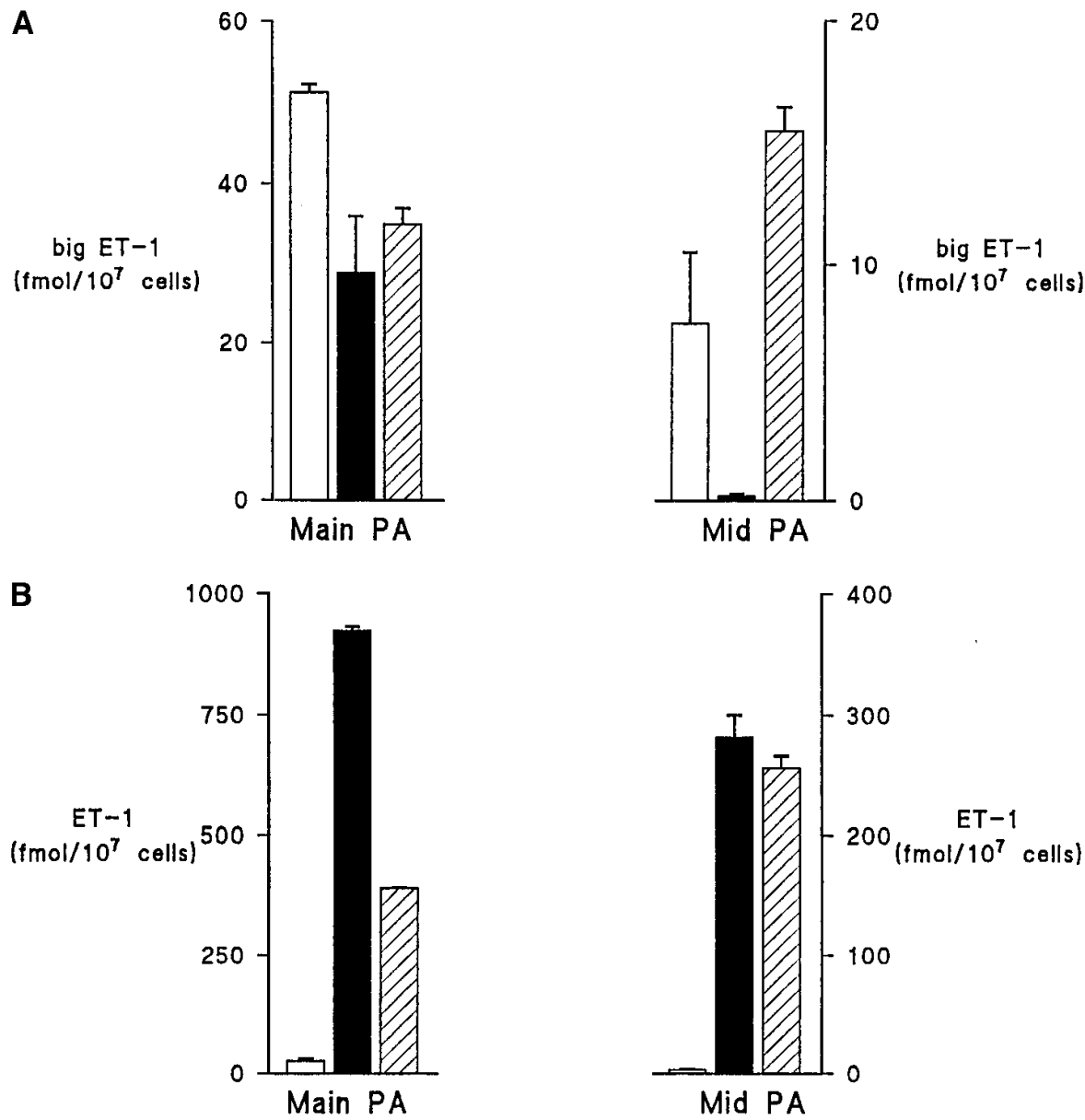

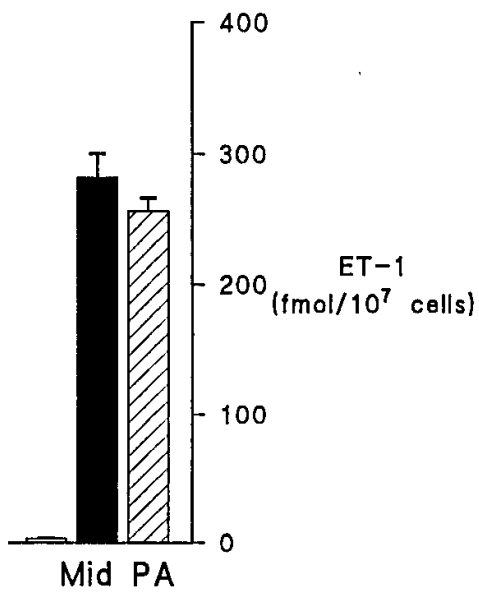

Figure 7. Concentrations of $(A)$ big ET-1 and $(B)$ mature ET-1 in SMC cultured from the main and midregion pulmonary artery $(P A)$ after $18 \mathrm{~h}$ incubation with either media alone (white bars), $10 \mathrm{nM}$ ET-1 (black bars), or ET- 1 plus $100 \mathrm{ng} / \mathrm{ml} \mathrm{TGF-} \beta$ (cross-hatched bars). Data are presented as mean \pm SEM from replicates of three different cell lines. 
ter) arteries, the appearance of muscle in normally nonmuscular peripheral arteries, and reduction in peripheral arterial volume $(1,2,12,20)$. The stimulus to the development of $\mathrm{CPH}$ is not clear. In a previous study, we suggested that TGF- $\beta$ may contribute to the CAE-induced structural remodeling; striking increases in TGF- $\beta$ mRNA and protein in the lung and pulmonary arteries are temporally associated with the development of $\mathrm{CPH}$ (21). In addition, changes in the walls of the muscular arteries are likely to include a response to the increased intraarterial pressure and to endothelial injury, seen as the early development of permeability edema $(1,22)$. Published data also indicate that altered levels of ET-1 mRNA and protein contribute to the development of pulmonary hypertension.

This study in sheep demonstrates that levels of ET-1 are increased in lung lymph during CAE while serum levels remain within the normal range; that expression of the ppET-1 gene by RT-PCR in control animals is high in the main pulmonary artery and lung, and relatively low in the midregion artery; and that this regional variation in ppET- 1 gene expression is maintained but reversed during the development of CAE-induced CPH. A dramatic fall in ppET-1 transcripts was found in the main pulmonary artery and lung; our findings with in situ hybridization are in line with these findings. Conversely, ppET-1 gene expression showed a modest and gradual increase in the midregion artery. In confirmation of these differential findings, we found that ppET-1 gene expression and intracellular concentrations of big ET-1 and ET-1 are greater in SMC isolated from the main than the midregion pulmonary artery of control animals, and that responsivity between the two cell types to exogenous ET-1 and ET-1 plus TGF- $\beta$ is different.

Differential ppET-1 gene expression in normal pulmonary artery and in lung. This study is the first to demonstrate regional variability in ppET-1 gene expression in the lung and main and midregion pulmonary artery of control animals. The differences in expression are perhaps not unexpected, since endothelial cells cultured from the main pulmonary artery and peripheral lung behave differently in response to inflammatory agents, e.g., TNF- $\alpha$ and endotoxin $(17,18)$, and heterogeneity of prostacyclin and thromboxane release has been shown in isolated vascular segments from ovine lung (23). Since both endothelial cells and SMC are known to synthesize ET-1 (24, 25 ), it is likely that both cell types contribute to the normally high levels of ppET-1 in the main pulmonary artery, a notion confirmed by studies in cultured SMC. The lower levels of ppET-1 gene expression in the midregion artery may reflect the thinner medial coat of an artery of this size and a difference in phenotype of the SMC in each region (26-28). Our data are the first demonstration that SMC isolated from the main and midregion artery synthesize different levels of ET-1. The lower levels of ppET-1 gene expression in the midregion artery suggest that vascular tone in this size of artery may not require local ET-1 synthesis. Alternatively, vascular tone in this region may be regulated by ET-1 released from the upstream artery. Such a regulatory mechanism has been shown for the kidney (29). In the lung, it is likely that the endothelial cells of the extensive capillary bed contribute to the normally high expression of the ppET-1 gene. However, it must be remembered that other peripheral lung cells and those in the walls of bronchioli and larger airways synthesize ET-1 and may also contribute (see references 30-32).

Effect of CAE on lung lymph ET-1 and lung ppET-1 gene expression. Alterations in ET-1 have been demonstrated in patients with primary and secondary pulmonary hypertension and in rat models of $\mathrm{CPH}$, but the changes are inconsistent. ET-1 mRNA was shown to increase in pulmonary endothelial cells of patients with either primary or secondary pulmonary hypertension (8) and in lungs of rats with either idiopathic pulmonary hypertension or after exposure to hypoxia $(9,10)$. However, lungs with monocrotaline-induced $\mathrm{CPH}$ showed reduced expression of ppET-1 mRNA (11). Further, plasma levels of ET-1 were increased in monocrotaline-induced CPH but unaltered in rats with idiopathic pulmonary hypertension $(9,11)$. In the present study, ET-1 concentrations were increased in lung lymph but not in plasma during CAE. The large dilution of ET-1 in blood versus that in lung lymph is likely to account, at least in part, for the low levels in blood. Thus, the pattern of ppET-1 gene expression is distinct in different forms and models of $\mathrm{CPH}$, and circulating ET-1 levels do not seem to reflect the alterations in the lung and pulmonary vascular bed (33). CAE results in an increase in endothelial permeability and endothelial injury in small vessels within $4 \mathrm{~h}$ of initiation of CAE $(1,34)$. Therefore, it is likely that the early and abrupt drop in ppET-1 expression in the lung reflects this early injury. Vasoconstriction of the small arteries, reduction in capillary surface area, and damage to other cells that synthesize ET-1 may also contribute to the drop in ppET-1 transcripts.

Metabolization of ET-1 has been shown to occur in alveolar capillaries of isolated perfused rat lung (35). We suggest that the increased levels of ET-1 in lung lymph during CAE are the result of a shift in equilibrium between ET-1 production and its normal elimination due to injury of tissue, particularly capillary endothelial cells. Patients with primary pulmonary hypertension have been shown to have decreased clearance of ET-1 by the lung; levels of ET-1 in pulmonary venous blood were higher than those in the pulmonary artery (4). Thus, our results are consistent with the notion that alterations in ET-1 concentration in lung's interstitium may contribute to the onset and maintenance of the functional and structural changes of $\mathrm{CPH}$, and further, that such increases in ET-1 may modulate ppET-1 gene expression and increased ET-1 synthesis in pulmonary artery SMC.

ET-1 and structural remodeling in main and midregion pulmonary artery and the contribution of SMC. The regional variability in ppET-1 transcripts in lung and the two levels of artery persisted during CAE, but was reversed. It is possible that the reduction in ppET-1 gene expression in the main pulmonary artery and the gradual increase in the midregion artery parallel the development of structural and functional changes in these regions (12). In the main pulmonary artery, the increased thickness and remodeling of the arterial wall is a secondary event. After CAE to granulocyte-depleted sheep, medial thickening occurred without the onset of a sustained increase in $P_{\mathrm{pa}}$ and PVR (2). The fall in ppET-1 gene expression at this level is perhaps the result of vascular wall injury and alterations in phenotype of the smooth muscle (and endothelial) cells as a consequence of the increased resistance. In situ hybridization studies of adjacent tissues taken from main pulmonary artery and lung failed to demonstrate which cell(s) was involved, because of the low level of signal in both normal and hypertensive lungs. ET-1 is known to regulate its own expression (36). Our studies with cultured pulmonary artery SMC clearly suggest that local alterations in ET-1 regulate ET-1 synthesis in SMC from the main pulmonary artery. 
The midregion pulmonary artery differs in structural response to CAE from the main pulmonary artery in that $50 \%$ of the midregion arteries show dramatic intimal thickening and proliferation of smooth muscle-like cells as well as increased medial thickness $(12,20)$. We suggest that the increased $P_{\text {pa }}$ and arterial remodeling contribute to the gradual increase in ppET-1 gene expression in the midregion artery. Local mediators of arterial remodeling, such as TGF- $\beta$, may also contribute to the air-induced structural remodeling and increase in ppET-1 gene expression, and our cell studies are consistent with that notion.

This study shows that exogenous ET-1 decreases the concentration of big ET-1 in SMC of the main and midregion artery while levels of mature ET-1 increase. These divergent findings may reflect phenotypic differences in the two SMC and/or be the result of ET-1-induced alterations in ECE activity. Further, the increases in intracellular ET-1 may reflect uptake of exogenous ET-1 (37) and binding of exogenous ET-1 to its high affinity receptors (38).

TGF- $\beta$ and ET-1 synthesis in SMC from main and midregion artery. Our findings suggest that TGF- $\beta$ modulates ET-1 synthesis in SMC and that this modulation differs at the two levels of artery examined. Big ET-1 concentrations were increased in the presence of ET- 1 plus TGF- $\beta$ compared with ET-1 alone only in SMC of the midregion, whereas ET-1 plus TGF- $\beta$ decreased intracellular levels of mature ET-1 only in SMC of the main artery. The reason for these differences is not clear. However, as for ET-1 alone, the differences are likely to include alterations in ECE activity as well as phenotypic differences in these two populations of arterial SMC. The striking increase in big ET-1 in SMC of the midregion artery in response to ET- 1 plus TGF- $\beta$ supports the increased ppET- 1 gene expression in arterial tissue at this level during CAE. Further, it is likely that ppET-1 expression in the midregion artery includes modulation of SMC and perhaps migration and proliferation of smooth muscle-like cells in the thickened intima. Increased ppET-1 mRNA has been shown in vascular SMC from the aorta of hypertensive rats (36) and from human omental vessels (24) in response to growth factors. Such findings suggest that increased ppET- 1 gene expression in the midregion artery may be linked to altered synthesis of growth factors, such as TGF- $\beta$, and intimal hyperplasia. The findings for the main pulmonary artery SMC are less clear, although it is likely that SMC are responsible, at least in part, for the reduction in ppET-1 gene expression during CAE.

In summary, we have shown for the first time that ppET-1 gene expression in the main pulmonary artery and lung of normal sheep is strikingly greater than in the midregion artery and that these regional variations in expression may be linked to differences in SMC phenotype. This differential expression of ppET-1 transcripts is reversed during the development of airinduced CPH when ppET-1 gene expression is downregulated in both the main pulmonary artery and lung and increases gradually in the midregion artery. We conclude that early injury to the lung's microvasculature is likely to contribute to the abrupt decrease in ppET-1 gene expression in the lung. Since the lung is a major organ responsible for metabolizing ET-1, we suggest that the increase in lung lymph ET-1 during CAE is the result of its decreased clearance, perhaps reflecting the CAE-induced endothelial perturbation and peripheral vascular changes. In the structurally remodeled pulmonary arteries, normal differences in SMC phenotype as well as the CAE- induced remodeling at each level and/or alterations in their phenotype, may contribute to the differential expression of the ppET-1 gene and ET-1 synthesis. Local production of growth factors may also modulate SMC function and ET-1 synthesis. Further studies are needed to explore these notions in detail, including assessments of ECE activity and ET-1 synthesis in SMC isolated from both levels of the remodeled pulmonary arteries.

\section{Acknowledgments}

We would like to thank Dr. Michael Dikov for his help in designing the primers and for his advice during the development of the RTPCR technique.

This work was supported by National Institutes of Health grant HL-48536.

\section{References}

1. Perkett, E.A., K.L. Brigham, and B. Meyrick. 1988. Continuous air embolization into sheep causes sustained pulmonary hypertension and increased pulmonary vasoreactivity. Am. J. Pathol. 132:444-454.

2. Perkett, E.A., K.L. Brigham, and B. Meyrick. 1990. Granulocyte depletion attenuates sustained pulmonary hypertension and increased pulmonary vasoreactivity caused by continuous air embolization in sheep. Am. Rev. Respir. Dis. 141:456-465.

3. Inoue, A.M., S. Yanagisawa, Y. Kimura, T. Kasuya, K. Miyauchi, K. Goto, and T. Masaki. 1989. The human endothelin family: three structurally and pharmacologically distinct isopeptides predicted by three separate genes. Proc. Natl. Acad. Sci. USA. 86:2863-2867.

4. Stewart, D.J., R.D. Levy, P. Cernacek, and D. Langleben. 1991. Increased plasma endothelin-1 in pulmonary hypertension: marker or mediator of disease? Ann. Int. Med. 114:464-469.

5. Shimada, K., M. Takahashi, and K.J. Tanzawa. 1994. Cloning and functional expression of endothelin-converting enzyme from rat endothelial cells. $J$. Biol. Chem. 269:18275-18278.

6. Barnes, P.J. 1994. Endothelins and pulmonary diseases. J. Appl. Physiol. 77:1051-1059.

7. Hassoun, P.M., V. Thappa, M.J. Landman, and B.L. Fanburg. 1992. Endothelin-1: mitogenic activity on pulmonary artery smooth muscle cells and release from hypoxic endothelial cells. Proc. Soc. Exp. Biol. Med. 199:165-170.

8. Giaid, A., M. Yanagisawa, D. Langleben, R.P. Michel, H. Levy, H. Shennib, S. Kimura, T. Masaki, W.P. Duguid, and D.D. Stewart. 1993. Expression of endothelin-1 in the lungs of patients with pulmonary hypertension. N. Engl. J. Med. 328:1732-1739.

9. Stelzner, T.J., R.F. O'Brien, M. Yanigisawa, T. Sakurai, K. Sato, M Weeb, M. Zamora, I.F. McMurtry, and J.H. Fisher. 1992. Increased lung endothelin-1 production in rats with idiopathic pulmonary hypertension. Am. J. Physiol. 262:L614-L620.

10. Elton, T.S., S. Oparil, G.R. Taylor, P.H. Hicks, R.H. Yang, and Y.F. Chen. 1992. Normobaric hypoxia stimulates endothelin-1 gene expression in the rat. Am. J. Physiol. 263:R1260-R1264.

11. Miyauchi, T., S. Yorikane, T. Sakurai, M. Okada, M. Nishikibe, M Yano, I. Yamaguchi, Y. Sugishita, and K. Goto. 1993. Contribution of endogenous endothelin-1 to the progression of cardiopulmonary alterations in rats with monocrotaline-induced pulmonary hypertension. Circ. Res. 73:887-897.

12. Perkett, E.A., J.M. Davidson, and B. Meyrick. 1991. Sequence of structural changes and elastin peptide release during vascular remodeling in sheep with chronic pulmonary hypertension induced by air embolization. Am. J. Pathol. 139:1319-1332.

13. Donahue, D.M., M.E. Lee, H.C. Suen, T. Quertermous, and J.C. Wain. 1994. Pulmonary hypoxia increases endothelin-1 gene expression in sheep. $J$. Surg. Res. 57:280-283.

14. Perkett, E.A., R.W. Pelton, B. Meyrick, and L.I. Gold. 1994. Expression of transforming growth factor- $\beta$ mRNAs and proteins in pulmonary vascular remodeling in the sheep air embolization model of pulmonary hypertension. Am. J. Respir. Cell Mol. Biol. 11:16-24.

15. Pelton, R.W., M.D. Johnson, E.A. Perkett, L.I. Gold, and H.L. Moses. 1991. Expression of TGF- $\beta_{1}, \beta_{2}$ and $\beta_{3}$ mRNA and protein in the murine lung. Am. J. Respir. Cell Mol. Biol. 5:522-530.

16. Thomae, K.R., C.J. Pratibha, P. Davies, B.R. Pitt, T.R. Billiar, R.L. Simmons, and D.K. Nakayama. 1996. Nitric oxide produced by cytokine-activated pulmonary artery smooth muscle cells is cytotoxic to cocultured endothelium. Surgery (St. Louis). 119:61-66.

17. Meyrick, B., B.W. Christman, and G. Jesmok. 1991. Effects of recombi- 
nant tumor necrosis factor alpha on cultured pulmonary artery and lung microvascular endothelial monolayers. Am. J. Pathol. 138:93-101.

18. Meyrick, B., R. Hoover, M.R. Jones, L.C. Berry, Jr., and K.L. Brigham. 1989. In vitro effects of endotoxin on bovine and sheep lung microvascular and pulmonary artery endothelial cells. J. Cell. Physiol. 138:165-174.

19. Gossage, J.R., E.A. Perkett, J.M. Davidson, B.C. Starcher, D. Carmichael, K.L. Brigham, and B. Meyrick. 1995. Secretory leukoprotease inhibitor attenuates lung injury induced by continuous air embolization into sheep. $J$. Appl. Physiol. 79:1163-1172.

20. Perkett, E.A., D.B. Badesch, M.K. Roessler, K.R. Stenmark, and B. Meyrick. 1992. Insulin-like growth factor and pulmonary hypertension induced by continuous air embolization in sheep. Am. J. Respir. Cell Mol. Biol. 6:82-87.

21. Perkett, E.A., R.W. Pelton, B. Meyrick, L.I. Gold, and D.A. Miller. 1994. Expression of transforming growth factor- $\beta$ mRNAs and proteins in pulmonary vascular remodeling in the sheep air embolization model of pulmonary hypertension. Am. J. Respir. Cell Mol. Biol. 11:16-24.

22. Tozzi, C.A., D.L. Christiansen, G.J. Poiani, and D.J. Riley. 1994. Excess collagen in hypertensive pulmonary arteries decreases vascular distensibility. Am. J. Respir. Crit. Care Med. 149:1317-1326.

23. Ilbe, B.O., R.M. Hillyard, and J.U. Raj. 1996. Heterogeneity in prostacyclin and thromboxane synthesis in ovine pulmonary vascular tree: effect of age and oxygen tension. Exp. Lung Res. 22:351-374.

24. Resink, T.J., T. Resink, T. Scott-Burden, J. Powell, E. Weber, and F.R. Buhler. 1990. Inducible mRNA expression and peptide secretion in cultured human vascular smooth muscle cells. Biochem. Biophys. Res. Commun. 168:1303-1310.

25. Yanagisawa, M., H. Kurihara, S. Kimura, Y. Tomobe, M. Kobayashi, Y. Mitsui, Y. Yazaki, K. Goto, and T. Masaki. 1988. A novel potent vasoconstrictor peptide produced by vascular endothelial cells. Nature. 332:411-415.

26. Frid, M.G., E.P. Moiseeva, and K.R. Stenmark. 1994. Multiple phenotypically distinct smooth muscle cell populations exist in the adult and developing pulmonary arterial media in vivo. Circ. Res. 75:669-681.

27. Stiebellehner, L., M.F. Ferguson, M.G. Frid, and K.R. Stenmark. 1997. Comparative analysis of the growth characteristics of smooth muscle cells iso- lated from proximal and distal bovine pulmonary artery. Am. J. Respir. Crit. Care Med. 155:A636. (Abstr.)

28. Archer, S.I., J.M. Huang, H.L. Reeve, V. Hampl, S. Tolarova, E. Michelakis, and E.K. Weir. 1996. Differential distribution of electrophysiologically distinct myocytes in conduit and resistance arteries determines their response to nitric oxide and hypoxia. Circ. Res. 78:431-442.

29. Kon, V., R.C. Harris, and I. Ichikawa. 1990. A regulatory role for large vessels in organ circulation. Endothelial cells of the main renal artery modulate intrarenal hemodynamics in the rat. J. Clin. Invest. 85:1728-1733.

30. Michael, J.R., and B.A. Markewitz. 1996. Endothelins and the lung. Am. J. Respir. Crit. Care Med. 154:555-581.

31. Markewitz, B.A., D.E. Kohan, and J.R. Michael. 1995. Endothelin-1 synthesis, receptors and signal transduction in cloned rat alveolar epithelial cell line: evidence for an autocrine role. Am. J. Physiol. 268:L192-L200.

32. Mariassy, A.T., M.K. Glassberg, M. Salathe, F. Maguire, and A. Wanner. 1996. Endothelial and epithelial sources of endothelin-1 in sheep bronchi. Am. J. Physiol. 270:L54-L61.

33. Battisini, B., P. D'Orleans-Juste, and P. Sirois. 1993. Endothelins: circulating plasma levels and presence in other biologic fluids. Lab. Invest. 68:600-628.

34. Albertine, K.H. 1988. Lung injury and neutrophil density during air embolization in sheep after leukocyte depletion with nitrogen mustard. Am. Rev Respir. Dis. 138:1444-1453.

35. Westcott, J.Y., J. Henson, I.F. McMurtry, and R.F. O'Brien. 1990. Uptake and metabolism of endothelin in the isolated perfused rat lung. Exp. Lung Res. 16:521-532.

36. Hahn, A.W.A., T. Resink, T. Scott-Burden, J. Powell, Y. Dohi, and F.R. Buhler. 1990. Stimulation of endothelin mRNA and secretion in rat vascular smooth muscle cells: a novel autocrine function. Cell Regul. 1:649-659.

37. Frelin, C., and D. Guedin. 1994. Why are circulating concentrations of endothelin-1 so low? Cardiovasc. Res. 28:1613-1622.

38. Waggoner, W.G., S.L. Genova, and V.A. Rash. 1992. Kinetic analyses demonstrate that the equilibrium assumption does not apply to $\left[{ }^{125} \mathrm{I}\right]$ endothelin-1 binding data. Life Sci. 51:1869-1876. 